\title{
The influence of technology determinism in forming criminal act of legislation
}

\author{
Agus Raharjo $^{1 *}$, Yusuf Saefudin ${ }^{2}$, and Rini Fidiyani ${ }^{3}$ \\ ${ }^{1}$ Criminal Law Department, Faculty of Law, Jenderal Soedirman University, Purwokerto - Indonesia \\ ${ }^{2}$ Indonesian Teachers' Association of Victimization J1. Prof. dr. HR Boenyaim 708 Purwokerto - Indonesia \\ ${ }^{3}$ Law and Society Department, Faculty of Law, Semarang State University, Semarang - Indonesia
}

\begin{abstract}
Technology has entered the human physical and spiritual existence. Technology is the reflection of the human soul in nature, it is the materialization of ideas in the human brain itself. Humans are increasingly fragmented and machines are increasingly dominant in human life, which causes problems in various fields, one of the fields is a law on the formulation of criminal acts in various legislation. To clarify this problem, normative research methods are used with a focus on comparative legislation. Laws of increasingly technological and technological nature adopt legal features in the work of science and technology. Lawmakers make rules that reflect technological determinism as well as against it. They glorify technology as well as make technology as one of the factors of criminal liability. This seems in the comparison between general criminal law legislation that originates from the Criminal Code with other laws and regulations that contain technological elements. Technology-based criminal penalties in general criminal law are unknown, and this only arises after the technology is used to commit criminal acts, such as in criminal acts of decency, humiliation, defamation, and crime dimension technology. This rationale needs to be deciphered considering the lawmakers is poor to give an explanation.
\end{abstract}

Keywords: technological determinism, technological indeterminism, criminal law, criminal liability, punishment

\section{Introduction}

Every country believes that the science and technology are the one of an important factor in sustaining the growth and progress of the state and in the context of economic development, technology can play a role as an engine of economic growth [1]. Science and technology have become ideologies, amulets, a sign of passport or entry to prosperity and justice, and cause a new cult as a consumptive society [2]. Technology is seen as a means of liberation, a media of democracy and participation, and can realize human autonomy, on the other hand technology can also act as a shackle for human freedom. When human values are corrupted, restricted and shut down by values of "function" and "pragmatism," technology will become an effective tool of destruction and oppression [3].

The level of development of a technology requires the support of the cultural values and socio-economic institutions of society in which the technology exists and is developed. Efforts to create a system that requires an understanding of the various life systems that already exist, because of the people's creation system that can only be formed by altering or synthesizing existing system structures. Scientific efforts provide a basic information for technological efforts, which in turn is strongly influenced by the cultural values adopted. However, it should be noted that a society with a high scientific culture is not necessarily strong in technology [4].

* Corresponding author: agus.raharjo007@gmail.com

The law is basically technology as well by referring to the use the term legal mode of production by Trubek, where the word production is a distinctive word or attached to technology. Moreover, the law works through an organization so it can be known who is acting as what on the legal mode of production track, but they are interconnected and working towards the perfection of the "legal machine". Another fact is the use of the term which later became the "law as a tool of social engineering" doctrine, which was first introduced by Roscou Pound [5, 6]. Given the fact that law is technology, then the use of laws to encourage technological progress or otherwise is something reasonable.

Law is often used as a means of control to prevent the use of technologies that bring harm to humans and nature. Criminal laws related to criminal matters are sometimes unable to reach or are unable to solve tech crime or crime problems using advanced technology [5, 7], that caused by lawmakers and law enforcement who are still confined 
by way of positivist thinking. This way of thinking requires the rule before the evil exists, so the evil that exists but there is no rule, then the crime will be left away [8-10]

The first step in crime prevention in such a way of thinking is by making the rules (written) in the legislature as a law-making machine. The workings of this machine have peculiarities that may not be the same as the workings of machines in general, because the human involved in, not a tool. However, the results of this machine work can illustrate the tendency of the views of lawmakers to technology, whether they belong to the class of determinism or tech indeterminism. Beside as a machine that can control the human, the law also can be used as a tool of social engineering. Related to that issue, the law can be used (through first stage of legislation process and execution on the next stage by law enforcer) for pulling low carbon usage in development process. Controlling carbon usage will help the people increase their health prosperity. This paper will compare the results of how the machine works against several laws that make technology one of the reasons for the law, and its effect on the development of theory in criminal law, especially on the question of the reasons for criminal liability.

\section{Method}

The method used for this research is normative juridical, emphasize on norms in legislation, theory and doctrine related to criminal and punishment; and comparative legislation. The research specification is descriptive. The data used in this research is secondary data with the main material in the form of primary law material (legislation). For the technological aspect, a literature search is conducted in combination with philosophical studies. The data obtained were analyzed using qualitative analysis.

\section{Discussion}

\subsection{Technological Determinism and The Change of Human Behavior}

Technology has grown so rapidly, even beyond what humans had predicted. Nevertheless, technological progress must remain in human control, so that positive or negative impacts can be predicted or the role of technology in life is restored to the service of human welfare [11-17]. The opinion shows that between humans and science and technology there is a reciprocity or symbiotic relationship if the limits of the use of technology are used in accordance with the needs of human beings as a tool to relieve or free the workload. When the technology is used in excess, the dehumanization will happen because humans lose the role and function in life, both as a social creature and even spiritual, can even occur culling of humans.

Nevertheless, until now there is an opinion that states that technology is the main actor behind the social changes that exist in society. The notion of deafening technology as the main actor and the only decisive factor in social change is called technological determinism. Technological determinism stems from determinism in the study of philosophy. The study of determinism is often associated with human freedom in taking action, choice or decision. Mark Rowlands [18] defines determinism as a combination of two types of claims, the first claim on the cause and the second claim to the consequences allegedly caused by the cause of human freedom:

a. Everything that exists or happens, including actions or deeds, human choices and decisions has a cause;

b. Therefore, human actions or deeds, choices, and decisions are not free.

The underlying concept of determinism is that causes cause inevitable effects. Everything that exists or happens is a cause, then every action we take, every choice and decision we choose, there will be a cause. All of these causes will have a cause, and all the causes of the cause there is a cause. In the end, we will surely arrive at a cause we can not control, so we will not be able to control the choice of judgment, and the action that ultimately occurs because of the cause. This, in essence, solves the argument of determinism [18].

This determinism gets opposition from indeterminism. The claim of determinism is rejected by indeterminism which proposes two main claims. First, at least human actions, or choices, and decisions have no cause; and second, therefore, actions, choices, and decisions that have no cause are free. Indeterminism is not bounded by the concept that all human actions, choices, and decisions are free. They can still accept that some of these three things have a cause, and if they do, they are not free. The point is that at least some human actions, choices, and decisions have no cause, and if this happens, then the action, choice, and decision are free: it is said to be free because there is no cause [18].

Technological determinism by Merritt Roe Smith interpreted as "the belief in technology as a key governing force in society ...", while Micheal L. Smith interprets it as "... the belief that social progress is driven by technological innovation, which in turn follows an "inevitable" course". For Bruce Bimber, technological determinism is "The idea that technological development determines social change ..." [19]. W.F. Ogburn considers that the technological determinists are those who say that it is technology that controls social structures and cultural rules. Marxist thought is unclear about this, but it is clear that Marxist economic determinism in its reality is technological determinism, because the control of the means of production - which, according to Marx, is the basis for all economic and social systems - is primarily a function of character that changes from the way of production [20].

According to Feenberg, there are two positions or premises of this determinism. First, technical progress appears to follow a unilinear course, a fixed track, from less to more advanced configurations; and second, technological determinism also affirms that social institutions must adapt to the "imperatives" of the technological base). Both premises are untenable because of unilinear technological developments, where technological developments to the highest levels are not only technological factors, other social (cultural, 
economic, political, and technological factors) play a role [21]. However, this deterministic view is still dominant in the media and popular culture.

Technological determinism is a troublesome concept, because it gives so serious attention to the development of technology, but negates the social factors that work when a society interacts with the technology. The doubts on technological determinism were put forward by some thinkers, such as Merrit Roe Smith, Leo Marx, David Noble and Andrew Feenberg. They see technological determinism as inclined to impose the workings of technological systems on societies that produce serious social, political and cultural impacts [22].

\subsection{Technological Determinism in The Criminal Law Product}

The orientation of the future development of criminal law does require adjustment in the regulation, either due to internal factors (from the weaknesses of the criminal law itself) and extrinsic factors derived from outside the penal law (such as the development of science and technology, or the result of an international convention discussing the development of crime) [23-24]. One of the operational characteristics of the development and formation of future material criminal law according to Muladi [25] and Atmasasmita [26] is responsive and in line with the development of science and technology in order to improve the effectiveness of its function in society. This is necessary given that technological advance of society often carries side effects, such as crime [27].

The advancement of information technology (internet) has brought people to a new dimension in life, as well as a new dimension in crime (cybercrime) [28]. Law enforcement officials are confused because of the absence of rules and technological factors that are not understood [7]. This is the need for an epistimological dialogue between law and technology so that there is no gap in thinking and understanding in handling the technological crime [5]. The insensitivity in anticipating the development of information technology will lead to softening or expansion or shift and even extension to the fundamental principle of criminal law, namely the principle of legality [29, 30].

What about Indonesia's legislation to anticipate the development of such technology. There are three points of interest in this article. First, the state's commitment to protecting citizens from the adverse effects of technology development and use; secondly, in relation to legal products issued by lawmakers will reflect their views on technology; and thirdly, it is about the formulation of articles relating to criminal prosecution for perpetrators using technology will show a tendency to determinism or indeterminism.

In relation to the first issue, the state is committed to protecting its citizens by making some rules on several areas affected by technological developments. Nevertheless, the slow response of this country led to the impression that the legislation that emerged was stale when it was enacted. Referring to the explanation of seceral law (Electronic Information and Transaction Law
(Law No. 11/2008), Pornography Law (Law No. 44/ 2008), Broadcasting Law (Law No. 14/2008), Telecommunication Law (Law No. 36/1999), and Transfer Fund Law (Law No. 3/2011)) clearly visible lawmakers including dystopians, acknowledge that the development of information technology contributes to the advancement and change of human behavior, but also worries about the bad influence on morals, the nation's personality that threatens the life and social order of Indonesian society.

On the third issue, relating to the formulation of articles concerning criminal prosecution for perpetrators using technology. Public criminal law (sourced on Criminal Code) may be disregarded, but such deviations should be in accordance with the legal logic and legal awareness of the people, not to make technology - which is the only tool - as the basis of criminal charges. Some formulations of the articles in the law that contain the elements of technology, in fact have essentially similarities with the formulation of criminal offenses in criminal code, the difference lies in the use of technology and more severe criminal threats.

The system of criminal punishment formulation in the Criminal Code uses a single system and alternative. In specific Law, there is rarely a single formulation system, which is used as an alternative, cumulative, or cumulative-alternative formulation system. In general, special criminal threats are more severe than criminal penalties in general criminal acts caused by the formulation system of criminal threats or criminal types that may be imposed by judges. This explanation proves the initial premise that the use of technology in criminal offenses enables legislators to formulate a criminal threat that is more severe than a criminal offense in a similar criminal act contained in the Criminal Code. Indirectly, lawmakers make norms about criminal levies on criminal offenses using technological means, whereas the evil mental attitude (mens rea) does not seem to have much attention. Such criminal offenses clearly deviate from the provisions contained in the Criminal Code.

For example on the issue of pornography, criminal threat to criminal code maximum prison 1 years and 6 month or maximum forfeit IDR 3.000; when referring to Law No 11/2008 Article 27 paragraph (1) jo Article 45 paragraph (1), maximum prisons 6 years and/or maximum forfeit IDR 1 billion; and when referring to Law No. 44/2008, more varied criminal threat, namely minimum prison 6 month and maximum 12 years and/or maximum forfeit IDR 250.000.000 and maximum forfeit IDR 6 billion (article 4 paragraph (1) jo Article 29), minimum prison 6 month and maximum 6 years, and/or minimum IDR 3 billion (article 4 paragraph (2) jo paragraph 30), maximum prison 4 years and/or maximum forfeit IDR 2 billion (Article 5 jo Article 31), and involving the children on a crime of the threat plus $1 / 3$ of the maximum criminal threat. In addition to the issue of pornography, criminal weighting based on the use of technology lies in criminal acts of defamation, theft, gambling, extortion, threat of violence, fraud crime, destruction of goods, embezzlement, illegal access, hate speech, counterfeiting, etc. 
Based on these examples, there is a different threat of criminal punishment for perpetrators who use technology more heavily than the perpetrators of general criminal acts. This proves that the reason for criminal levitation is no longer placed on classical reasons in criminal law such as concursus, residive, offense (contained in Book 1 of the Criminal Code), or due to a particular circumstance or quality (contained in Book 2 and Book 3 of the Criminal Code). The use of technological tools the basis of criminal liability, shows the views of lawmakers who tend to be deterministic.

The claim that the legislator's deterministic view is based on several things. First, technology is seen as the main actor and the only factor determining the occurrence of crime; secondly, neglect of human freedom; and thirdly, the lawmakers event act like machine, as if Laws can solve problems in a flash accroding to technology promises.

The deterministic view of lawmakers is actually problematic, focusing too heavily on the role of technology in the realization of criminal offenses that lead to heavier criminal threats indicate they fail to understand the philosophy of technology. This view is in line with the substantive theory in technology that views technology underlying a new type of cultural system that reorganizes the whole world as an object of control. Feenberg [31] argues that when we choose to use a technology, we actually make unscrupulous cultural choices. Technology is not just meaningful, but has become a confusion and a way of life, this is a substantive impact (substantive impact).

There is something contradictory to lawmakers, they recognize that technology is neutral, but in criminal formulation, they are deterministic and substantive. Paradox is not only found in a single legislation, but the tendency of all the legislation that nuanced the technology. The possibility will be different if lawmakers are consistent in viewing technology or at least do not regard technology as a contributing factor, even if this view exists, it is certainly not necessary to create more and more legislation, it is sufficient to develop the method of interpretation of a passage from the law existing legislation containing the essence of the same deed.

If lawmakers are consistent and think technology is neutral, it will not make technology the culprit. If consistent, lawmakers can be categorized as instrumentalists in technology. The instrumental theory offers the broadest view of technology based on the general view that technology is a tool or tool that is ready to serve the purpose of its wearer. Based on this theory, technology is considered "neutral", regardless of the content of the technology itself. Technology has nothing to do with good or bad and can be used whatever is either political or social in accordance with the wishes of people or institutions. Technology is a "rational entity" and is generally accepted, followed by the same or similar standard of standards to be applied to different situations [31].

If the technology fails to reach its destination or when the negative effects of the technology emerge, then it is not the technology that is guilty, but the users of the technology are good politicians, military, big businessmen and others. It is not the gun that is problematic, but the man behind the gun is what should be the setting. Technology has entered the physical and spiritual existence of man. Humans not only direct nature, human beings themselves. Technology is the reflection of the human soul in nature, it is the materialization of ideas in the human brain itself. Machines and organizations are the fossilization of sociocultural interactions. So the problem really is not technology, but man himself [32].

This is the importance of lawmakers to understand the philosophy of technology so that in formulating legislation is not contradictory, does not hinder development and not make technology as a scapegoat. Technological policies must be conducted through indepth analysis, and the analyst must be fully aware that the existence of technology is linked to human beings or humanitarian problems, both in the process of creation and use. This explanation indicates that formulating a policy (or legislation) with a technology background, is not merely formulated in the chapter, but philosophical, technical and social entities should be considered, as the effects of the policy will reaching far consequences.

\section{Conclusion}

Formulating a legislation containing criminal acts and threats by making technology as the background, not just arranging words and sentences and ending with a criminal threat that is more severe than the criminal act in general. A single policy analysis framework between technical and social entities is required so that legislators do not get caught between technological determinism and indeterminism or between substantive and instrumental theory. If this is done, it will clearly position the legislator and its products from the philosophical and practical side. During this time, technological determinism is still a prima donna in the manufacture of technology-based rules that impact scapegoating technology as the cause of the crime. Something that give benefit and also the loss (carbon) must be controlled, and the law can be used for controlling by doing law function as a tool of social engineering. It needs comprehensive efforts to make lawmakers not to use technology as a scapegoat (which leads to criminal penalties), but as a factor driving positive progress and social change.

\section{Acknowledgement}

The writer would say thank you to every person who help and strengthen this research until this finished paper. First and fore most acknowledgments were presented to the Rector and Chairman of the Institute for Research and Community Service of the Jenderal Soedirman University who has provided research funding. The same remark was also conveyed to the Dean of the Faculty of Law, University of Jenderal Soedirman, along with staff who have given research permission and other file completeness. May good deeds get their reward from Allah SWT. 


\section{References}

1. J. Davidson Frame, International Business and Global Technology (DC Heat and Company, Lexington, 1984)

2. Jacob, Manusia, Ilmu dan Teknologi, Pergumulan Abadi dalam Perang dan Damai (PT. Tiara Wacana, Yogyakarta, 1993)

3. Miftah Wirahadikusumah, Logika dan Gramar Teknologi: Sebuah Tinjauan Psikoanalisis, Masyarakat: Jurnal Sosiologi 1 (1992)

4. Saswinadi Sasmojo dan Sonny Yuliar, Budaya Sains, Teknologi dan Perubahan Masyarakat, Seri Penerbitan Sains, Teknologi dan Masyarakat, Edisi I (2000), 35-36

5. Agus Raharjo, Hukum dan Teknologi, Suatu Tinjauan Filosofis dan Kritik Terhadap Positivisme Hukum (BP Undip, Semarang, 2007);

6. FX. Adji Samekto, Menggugat Relasi Filsafat Positivisme dengan Ajaran Hukum Doktrinal, JDH 12, 1 (2012), 74-84

7. Agus Raharjo, Cybercrime, Pemahaman dan Upaya Pencegahan Kejahatan Berteknologi (Citra Aditya Bandung, 2002)

8. Agus Raharjo, Angkasa dan Hibnu Nugroho, Rule Breaking dalam Penyidikan Untuk Menghindari Kekerasan yang Dilakukan oleh Penyidik, JDH 13, 1 (2013), 59-74

9. Kelik Wardiono, Basis Epistemologis Paradigma Rasional dalam Ilmu Hukum: Sebuah Deskripsi tentang Asumsi-Asumsi Dasar Teori Hukum MurniHans Kelsen, JDH 14, 3 (2014), 369-383

10. FX. Adji Samekto, Relasi Hukum dengan Kekuasaan: Melihat Hukum dalam Perspektif Realitas, JDH 13, 1 (2013), 89-98

11. Y.B. Mangunwijaya (ed), Teknologi dan Dampak Kebudayaannya, Vol. 1 (Yayasan Obor Indonesia, Jakarta, 1993)

12. Arifin Rada, Euthanasia sebagai Konsekuensi Kebutuhan Sains dan Teknologi (Suatu Kajian Hukum Islam), JDH 13, 2 (2013), 332-343

13. Endra Wijaya, Ricca Anggraeni, dan Rifkiyati Bachri, Desa Digital: Peluang Untuk Mengoptimalkan Penyebarluasan Peraturan Perundang-undangan di Indonesia, JDH 13, 1 (2013), 75-88

14. F.H. Edy Nugroho, Pemanfaatan Teknologi Informasi dalam Rangka Memberantas Tindak Pidana Korupsi Secara Elektronik, JDH 14, 3 (2014), 539546

15. Danrivanto Budhijanto, Peran Hukum Telekomunikasi terhadap Implikasi Konvergensi Teknologi Informasi dan Komunikasi, JDH 14, 1 (2014), 134150
16. Edi Wahjuni and Nuzulia Kumala Sari, Legal Aspect of Electronic Medical Records, JDH 17, 3 (2017), 314-319

17. Rini Fidiyani, Dewi Sulistianingsih, and Pujiono, Law and Ethics of Communicating in Social Media, JDH 17, 3 (2017), 258-265

18. Mark Rowlands, The Philosopher at the End of the Universe: Philosophy Explained Through Science Fiction Film (Mizan, Bandung, 2004)

19. Merritt Roe Smith and Leo Marx (eds), Does Technology Drive History? The Dilemma of Technological Determinism (MIT Press, Cambridge, 1994)

20. Victor C. Ferkiss, Technology and Industrial Man, Technology Man, The Myth and the Reality (George Braziller, New York, 1969)

21. Andrew Feenberg, Subversive Rationalization: Technology, Power and Democracy, Inquiry, 35: 1992, 3-4

22. Zulfikar Amir, Membuka Kotak Hitam Teknologi, Kompas, 3 March 2004

23. Madiasa Ablisar, Relevansi Hukuman Cambuk Sebagai Salah Satu Bentuk Pemidanaan dalam Pembaharuan Hukum Pidana, JDH 14, 2 (2014), 278-289

24. Loura Hardjaloka, Criminal Justice System of Children: An Overview Restorative Justice Concept in Indonesia and Other Countries, JDH 15, 1 (2015), 73-81

25. Muladi, Proyeksi Hukum Pidana Materiil di Masa Mendatang (Inauguration speech in professorship in Faculty of Law, Diponegoro University, 1990)

26. Romli Atmasasmita, Tindak Pidana Transnasional dalam Sistem Hukum Pidana Indonesia (Citra Aditya Bakti, Bandung, 1997)

27. Muladi dan Barda Nawawi Arief, 1992, Bunga Rampai Hukum Pidana (Alumni, Bandung, 1992)

28. Michael P. Dierks, Computer Network Abuse, Harv. J.L. \& Tech. 6 (1993)

29. Barda Nawawi Arief, Kapita Selekta Hukum Pidana (Citra Aditya Bakti, Bandung, 2003)

30. Ridwan, Critical Study to the Enforceability of Passive National Principle in Indonesia Criminal Code, JDH 15, 2 (2015), 186-192

31. Andrew Feenberg, Critical Theory of Technology (Oxford University Press, Oxford, 1991)

32. T. Jacob, Masa Depan: Mempelajari, Menyongsong dan Mengubahnya (Balai Pustaka, Jakarta, 1991) 